\title{
Defining the overlap between sporadic and attenuated familial adenoma risk
}

\author{
Thérèse M Tuohy ${ }^{1 *}$, Deborah W Neklason ${ }^{2}$, Kenneth M Boucher ${ }^{2}$, Richard G Pimentel ${ }^{1}$, Kerry G Rowe ${ }^{3}$, \\ Geraldine P Mineau ${ }^{1,2}$, Randall W Burt ${ }^{4}$ \\ From 14th Annual Meeting of the Collaborative Group of the Americas on Inherited Colorectal Cancer \\ Dallas, TX, USA. 12-13 October 2010
}

\section{Background}

Mutations in the $A P C$ gene lead to Familial adenomatous polyposis (FAP) and an attenuated form of this condition (AFAP). Based on previous work with mutation-verified patients from a large AFAP kindred, we showed that AFAP patients may be under-diagnosed, in the absence of a genetic diagnosis. For example, for patients between 30 and 79 years of age, $28 \%$ had fewer than 10 adenomas; 22\% had fewer than 6 adenomas, and $7 \%$ had no polyps. Therefore, depending on the number of adenomas considered more consistent with sporadic, rather than a familial predisposition, and the availability or lack of known family history, up to $\sim 25 \%$ of mutation-carrying AFAP patients may be missed in clinical practice. We sought to address this challenge by profiling mutation-independent adenoma formation among the mutation-negative carriers in this kindred.

\section{Methods}

Careful endoscopic evaluation of the AFAP cases has been previously reported, and these data were used for the mutation-positive individuals. The Utah Population Database (UPDB) includes Utah genealogies linked with medical records serving $85 \%$ of the Utah population. The database was queried for all descendents of known mutation-negative branches of this large kindred who had undergone colonoscopy procedures between 1995 and 2009. The queries collected data on age, gender, polyp type, pathology and cancer diagnoses, and were verified by manual review of randomly selected cases. Multiple logistic regression allowed us to characterize

\footnotetext{
* Correspondence: therese.tuohy@hci.utah.edu

${ }^{1}$ High Risk Cancer Clinics, Huntsman Cancer Institute, University of Utah, Salt Lake City, UT, USA

Full list of author information is available at the end of the article
}

the relative risk of a mutation, based on the adenoma profile of mutation carriers $v s$. non-carriers and additional covariates.

\section{Results}

A total of 135 colonoscopy records were collected and reviewed for 65 individuals who subsequently tested negative for the family mutation, at a median age of 51 (standard deviation of 16 years) and average pathologyconfirmed adenoma count of $0.25($ mode $=0)$ at first colonoscopy. For patients between 30 and 79 years of age, $5 \%$ had 2 or more adenomas; $17 \%$ had a single adenoma, and $79 \%$ had no adenomas. Additional comparable data were available on 130 individuals from negative branches of the kindred, who underwent colonoscopy between 1995 and 2009.

\section{Conclusions}

The combination of a long-running study with archived records and a large, electronically searchable medical database with a linked genealogical resource offers a powerful platform for the development of hypothesisdriven research. This resource may be used to address both clinical and research questions whose answers may be used to guide clinical management.

\section{Disclosure and funding}

There are no financial interests to disclose. This research was funded by NIH grants P01CA073992 (RWB); the Utah Population Database and the Huntsman Cancer Foundation.

\section{Author details}

${ }^{1}$ High Risk Cancer Clinics, Huntsman Cancer Institute, University of Utah, Salt Lake City, UT, USA. ²Dept. Oncological Sciences, Huntsman Cancer Institute, University of Utah, Salt Lake City, UT, USA. ${ }^{3}$ Dept. of Oncology, 
Published: 10 March 2011

doi:10.1186/1897-4287-9-S1-P37

Cite this article as: Tuohy et al:: Defining the overlap between sporadic and attenuated familial adenoma risk. Hereditary Cancer in Clinical Practice 2011 9(Suppl 1):P37.

Submit your next manuscript to BioMed Central and take full advantage of:

- Convenient online submission

- Thorough peer review

- No space constraints or color figure charges

- Immediate publication on acceptance

- Inclusion in PubMed, CAS, Scopus and Google Scholar

- Research which is freely available for redistribution

Submit your manuscript at www.biomedcentral.com/submit
C Biomed Central 